\title{
EMISSIONS FROM THE COMBUSTION OF SOLID BIOFUELS
}

\author{
Jerzy CHOJNACKI ${ }^{1}$, Juraj ONDRUŠKA ${ }^{2}$, Waldemar KUCZYŃSKI ${ }^{1}$, L'ubomír ŠOOŠ², \\ Błażej BALASZ ${ }^{1}$ \\ ${ }^{1}$ Koszalin University of Technology, POLAND \\ ${ }^{2}$ Slovak University of Technology in Bratislava, SLOVAKIA \\ E-mail of corresponding author: jerzy.chojnacki@tu.koszalin.pl
}

Keywords: solid biofuels, waste biomass, emissions

\begin{abstract}
Owing to the use of excess straw and unsold grain that has gone bad as a biofuel for heating boilers, farmers may save money to be spent on fuel and it allows them to gain additional profits from the sale of biomass that has not been used. In order to assess the usability of waste biomass as a fuel, tests were conducted related to the emission levels of particulate matter (PM), carbon oxide and nitric oxide that are emitted during combustion in the heating boiler of pellets from pine wood and from rape straw as well as a mixture of pine and rape pellet with lentil grain. The values of the emissions of the agents examined from the combustion of crop-based biomass exceeded by many time the values of emissions that occur as a result of the combustion of pine wood pellet only. The high levels of the emissions of particulate matter, carbon oxide and nitric oxide connected with the combustion of waste crop-based biomass may in the future discredit this material as a fuel for low emission boilers.
\end{abstract}

\section{INTRODUCTION}

In agricultural farms, there is an overproduction of waste biomass, i.e. unused straw and spoiled, damaged or unsold grain. An excess of biomass may be used by farmers as an energy material. Present-day heating boilers that use biomass granulate as a fuel are chiefly used with wood pellet, yet granulates from straw or hay as well as grain can be incinerated in these boilers. Owing to the use of energy materials from their own waste biomass to heat rooms, farmers may have significant savings in spite of the fact that farmers bears additional costs to process biomass into the pellet form (Kraszkiewicz et al., 2015). Another advantage of straw pelleting and storing it in the form of granulate is the high bulk density of this form of material; hence, the storage space in farms can be reduced (Niedziółka et al., 2015).

During the incineration of solid fuels, including crop-based fuels, there occurs an emission of substances into the atmosphere that are harmful to human health and to the natural environment. These are chiefly emissions of particulate matter and gases (e.g. Demirbas, 2005). The primary undesirable gas emissions include carbon monoxide: CO and nitric monoxides: $\mathrm{NO}_{\mathrm{X}}$ as well as polycyclic aromatic hydrocarbons (Olsson, 2006). The particulate matter contained in exhaust gases is related to liquefied fluid, incomplete combustion products and ash particles. These may also be fine underburnt biomass particles and ash particles that are removed from the boiler into the atmosphere by the rush of gases. Particulate matter suspended in air is divided into three subclasses, i.e. PM10, PM2.5 and PM0.1. The emission levels of pollutants contained in fumes from the incineration of biomass may significantly vary depending on the composition and type of fuel, fuel humidity, boiler capacity, incineration technology, the course of incineration and the thermal processes that occur there as well as the software that is used to control boilers (Bignal et al., 2008; Chojnacki at al., 2017; Hays et al., 2003; Johansson et al., 2003).

In modern heating boilers, with the aid of the control system installed in these and appropriate software, by dosing air and fuel that is fed into combustion chambers, it is possible to control the composition of emissions contained in exhaust gasses and to modify and control thermochemical processes (Romeo \& Gareta, 2006; Valíček et al., 2017). Dosing of fuel and air is done depending of the data obtained from sensors (e.g. temperature in the combustion chamber, oxygen excess ratio as well as the temperature of water in the water jacket, the temperature of fumes as well as $\mathrm{CO}_{\mathrm{X}}$ and $\mathrm{NO}_{\mathrm{X}}$ emissions). Permissible emission levels for boilers including a division into classes are contained in the PN-EN 303-5:2012 Standard. 
Following this Standard, the Ecodesign Directive will come into force starting from the year 2020. With regards to emissions, its requirements are the level of Class 5 of the PN-EN 3035:2012 Standard. Those farmers who will purchase modern boilers that guarantee emission levels according to this class will qualify for financial support from government anti-smog programs. Boilers including the software that controls their work are designed taking into consideration combustion of a selected fuel, e.g. pine wood pellet, so that the minimum emission levels as per Class 5 could be maintained while making a maximum use of the calorific value. Unfamiliarity with the level of emissions from the combustion of crop-based waste biomass from the farmer's own farm and replacing the fuel dedicated to given boilers with this biomass may lead to the levels permitted by the Standard being exceeded. This may result in the loss of the subsidy connected with the purchase of the boiler. To prevent this, emissions need to be determined from the combustion in "anti-smog" boilers of crop-based waste biomass of various type; investigations need to be initiated to create a composition of low emission fuels from this biomass that conform to the conditions related to fuels dedicated to boilers. Emissions of some substances during the combustion of biofuels may be reduced by the use of fuel additives and production of mixed fuels. The authors of the paper (Bäfver et al., 2009) investigated the impact of a calcium and kaolin additive to the fuel on changes in the emissions of particulate matter during the combustion of oat grains. It was found that a kaolin additive to oat grain may limit the emissions of particulate matter during its combustion. The research demonstrated that a two-percent share of kaolin in the fuel reduced particulate matter emissions by 31 per cent, while a four per cent additive reduced particulate matter emissions by 57 per cent. The authors of the paper (Fagerström et al., 2010) described examples of a reduction of the emissions of potassium and particulate matter by adding peat to the biofuel.

The purpose of the present research is an assessment of the level of the emissions of particulate matter, carbon monoxide and nitric monoxides in waste gases from the combustion of a composition of solid fuels from crop-based waste biomass in a heating boiler.

\section{MATERIAL AND METHODS}

Lentil grain, pine wood pellet and rape straw pellet were used as fuels in the investigations related to the emission levels of biofuels during incineration in a boiler. The diameter of the pellet used was $6 \mathrm{~mm}$. Lentil grain came from a cleaning plant and this was waste with mechanical damage. The compositions of the fuel inputs used were as follows: pine wood $100 \%$, pine wood $80 \%$ lentil grain $20 \%$, pine wood $20 \%$ lentil grain $80 \%$, rape straw $50 \%$ lentil grain $50 \%$, rape straw $100 \%$. The relative humidity of the fuels prepared did not exceed 6 per cent. The fuel was combusted in an automatic $25 \mathrm{~kW}$ heating boiler manufactured by Froling, type: P4 Pellet. This boiler possesses a double ash collector; the purpose of the other ash collector is to remove ash particles from fumes. It also possesses a condensation chamber that collects heat from the fuel that goes from the boiler to the stack. Pine wood pellet is the fuel that is dedicated to this boiler.

A Testo 380 fine particle analyser connected to a Testo 330-2 LL fumes analyser was used in the measurement of particle matter emissions as well as carbon monoxide and nitric monoxides in fumes. The analyser probe was installed in the stack over the boiler condensation module. The fume analyser made an automatic measurement over a period of 15 minutes. Additionally, with the aid of this analyser, the measurements were made of the fume temperature, fume humidity and oxygen share in the fumes. The test stand is presented in Fig. 1. The boiler was connected via pipes with a warm water tank. Heat from the boiler was collected indirectly by heating cold water that flowed through it which, once heated, was removed to a sewage system. The flow rate of water that chilled the tank was selected in such 
a manner so that water coming from the boiler to the tank and that heated it could maintain a constant temperature of $60^{\circ} \mathrm{C}$.

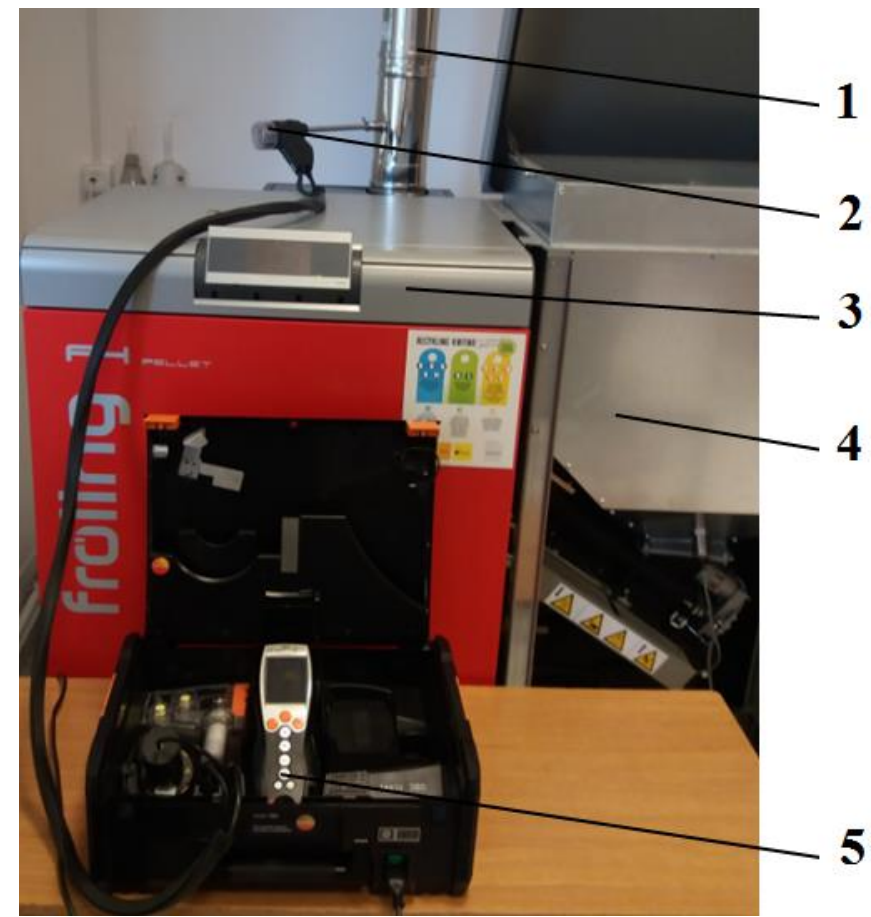

Fig. 1. Test stand: 1 - stack, 2 - probe, 3 - boiler, 4 - pellet container, 5 - analyser

\section{RESULTS AND DISCUSSION}

The values of the parameters of exhaust gases measured with the probe, such as: relative humidity, temperature and oxygen contents in exhaust fumes are presented in Table 1.

Tab. 1. Parameters of exhaust gases

\begin{tabular}{|l|c|c|c|c|c|}
\hline \multicolumn{1}{|c|}{ Name of parameter } & $\begin{array}{c}\text { Pine } \\
\text { wood } \\
100 \%\end{array}$ & $\begin{array}{c}\text { Pine wood } \\
80 \%, \text { lentil } \\
\text { grain 20\% }\end{array}$ & $\begin{array}{c}\text { Pine wood } \\
20 \%, \text { lentil } \\
\text { grain 80\% }\end{array}$ & $\begin{array}{c}\text { Rape straw } \\
50 \%, \text { lentil } \\
\text { grain 50\% }\end{array}$ & $\begin{array}{c}\text { Rape } \\
\text { straw } \\
100 \%\end{array}$ \\
\hline Humidity of exhaust gases, [\%] & 11.3 & 11.6 & 10.7 & 11.2 & 10.7 \\
\hline Temperature of exhaust gases, [C] & 54.9 & 54.9 & 55.5 & 56.3 & 54.9 \\
\hline Oxygen cont. in exhaust gases, [\%] & 15.2 & 15.2 & 15.2 & 15.2 & 15.1 \\
\hline
\end{tabular}

The results of the following measurements: particulate matter, carbon oxide and nitric oxides contained in exhaust fumes are presented in Figures 2, 3 and 4. The diagrams present the mass of the substances emitted that are contained in the mass of exhaust gases.

It is evident based on the diagrams that the combustion of a mixture of pellet from pine wood and lentil grain caused emissions that are by many times higher than the level of emissions from the combustion of pine wood pellet only. The results demonstrate that even a small addition (20 per cent) of lentil grain to pine wood pellet could cause a growth of the values of the emissions under investigation even by 100 per cent. The levels of emissions from the combustion of rape straw pellet only and mixed with lentil grain pellet also exceeded by many times the levels of emissions from the combustion of pure pine pellet. 


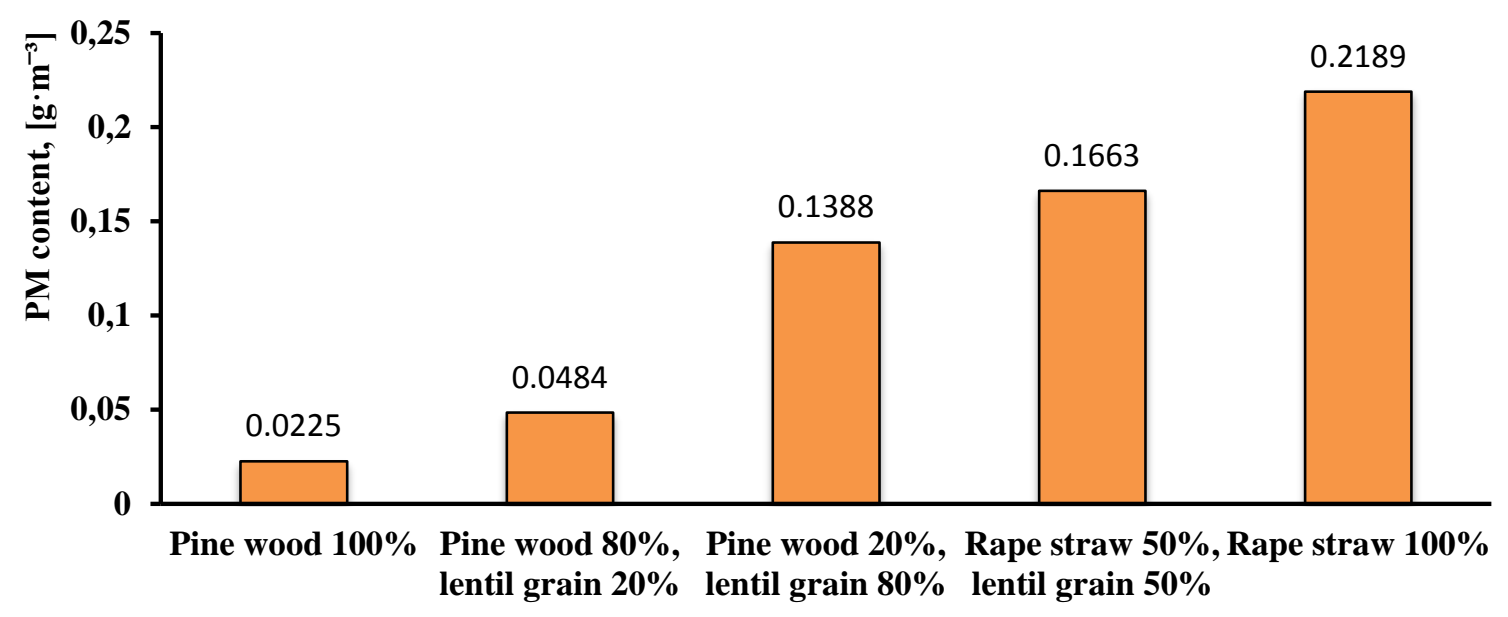

Kind of biofuel

Fig. 2. Particulate matter content in fumes

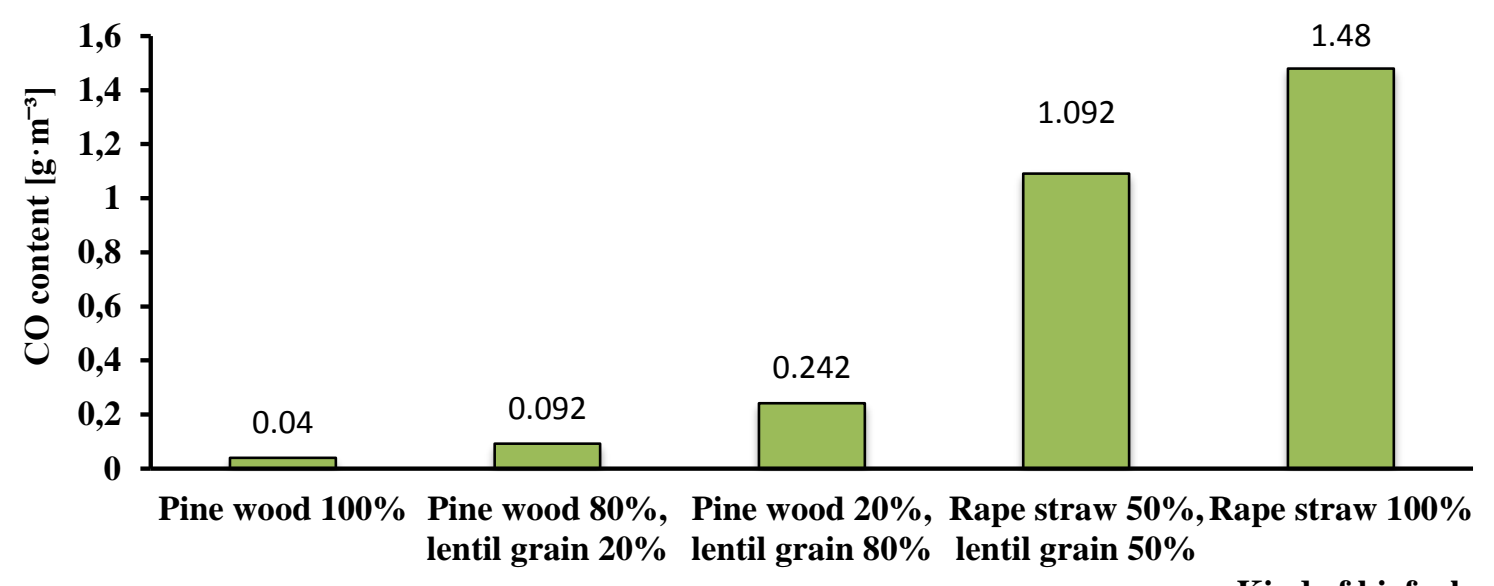

Kind of biofuel

Fig. 3. Carbon oxide content in fumes

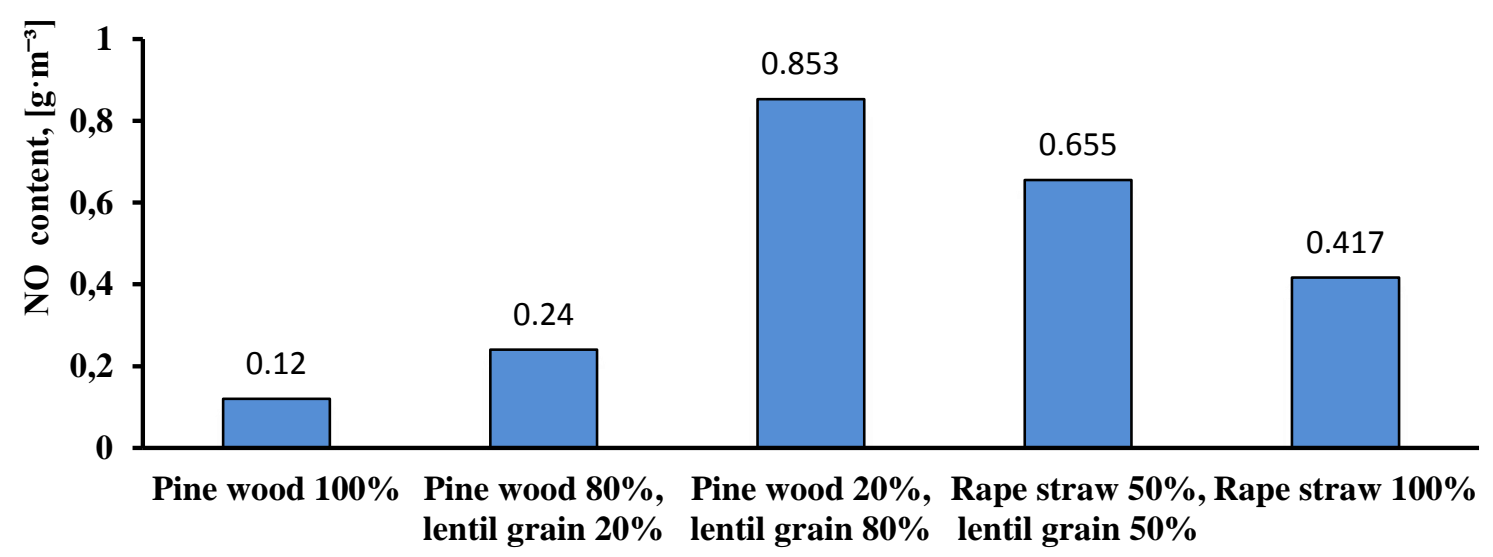

Kind of biofuel

Fig. 4. Nitric oxide content in fumes

During combustion, nitric oxides may form as a result of the reaction of atmospheric nitrogen with atomic oxygen in high temperatures, yet it is also oxidation of nitrogen compounds that are chemically bonded with the substance that is the main factor that has an impact on their 
value in exhaust fumes (Kraszkiewicz et al., 2015; Mitchell et al., 2016). According to the data contained in the articles (Chojnacki et al., 2017; Gulmezoglu \& Kayan, 2011; Komorowicz et al. 2009), the average nitrogen content in pine wood is from 0.13 to $0.5 \%$ of dry matter; in rape straw, this is ca. $0.8 \%$ and in lentil grains: from 3.4 to $4.4 \%$. When comparing this data with the results of tests related to nitric oxygen emissions, it may be stated that it is nitrogen contents in the biofuels under examination that had a major impact on the value of these emissions.

\section{CONCLUSIONS}

The following was established in the research:

- combustion in low-emission boilers of fuels from waste crop-based biomass such as rape straw or lentil grain may cause the occurrence of the emission levels of particulate matter, carbon oxide and nitric oxide that substantially exceed the emission levels that are permissible for this type boilers,

- co-combustion of crop-based products, like lentil grain in the experiment, with fuel dedicated for low-emission boilers (in this case, pine wood pellet) may also cause a significant increase of the level of the following emissions: particulate matter, carbon oxide and nitric oxide.

When relevant services find that permissible emission levels have been exceeded, those farmers who have used preferential credits or dedicated programs that support the purchase of low emission boilers may lose their financial privileges.

In order to utilize the unused potential of waste crop-based biomass as an energy material for low emission boilers, there is a need to develop and test formulas for low-emission fuels produced based on these materials.

\section{ACKNOWLEDGMENTS}

The subject of research was inspired by the Polish-Slovak project SK-PL-2015-0059, conducted in the years of 2016-17 and entitled "Development of low-emission solid fuels from biomass residues".

\section{REFERENCES}

Bäfver L. S., Rönnbäck M., Leckner B., Claesson F., Tullin C. (2009). Particle emission from combustion of oat grain and its potential reduction by addition of limestone or kaolin. Fuel Processing Technology, 90 (3), 353 359.

Bignal K. L., Langridge S., Zhou J. L. (2008). Release of polycyclic aromatic hydrocarbons, carbon monoxide and particulate matter from biomass combustion in a wood-fired boiler under varying boiler conditions. Atmospheric Environment, 42, 8863-8871.

Chojnacki: J., Berner B., Bujaczek R., Denis A., Onderová I., Ondruska J.. Piskier T., Rokosz K., Sławiński K. (2017). Emisje ze spalania paliw stałych z biomasy roślinnej. in: Postawowe problemy pozyskania energii odnawialnej, Copyright by Instytut Technologiczno-Przyrodniczy w Falentach (ITP), ISBN 978-83-65426-27-7, 27-29.

Demirbas A. (2005). Potential applications of renewable energy sources, biomass combustion problems in boiler power systems and combustion related environmental issues. Progress in Energy and Combustion Science. 31, (2), 171-192.

Fagerström, J., Näzelius, I.-L. Boström, D., Öhman, M., Boman, C. (2010). Reduction of fine particle- and deposit forming alkali by co-combustion of peat with wheat straw and forest residues. Available from: 
ttps://www.researchgate.net/publication/268341412_Reduction_of_fine_particle-

and_deposit_forming_alkali_by_co-combustion_of_peat_with_wheat_straw_and_forest_residues.

Gulmezoglu N., Kayan N. (2011). Dry Matter and Nitrogen Accumulation During Vegetative and Grain Filling of Lentil (Lens culinaris Medic.) as Affected by Nitrogen Rates. Not Bot Horti Agrobo, 39 (2). 196-202, Available from: www.notulaebotanicae.ro

Hays M. D., Fine P. M., Geron C. D., Kleeman M. J., Gullett B. K. (2005). Open burning of agricultural biomass: Physicaland chemical properties of particle-phase emissions. Atmospheric Environment 39, (36), 67476764.

Johansson L.S., Tullin C., Leckner B., Sj'ovall P. (2003). Particle emissions from biomass combustion in small combustors. Biomass and Bioenergy 25 (4), $435-446$.

Komorowicz M., Wróblewska H., Pawłowski J. (2009). Chemical composition and energetic properties of biomass from selected renewable resources. Ochrona Środowiska i Zasobów Naturalnych 40, 402-410.

Kraszkiewicz A., Przywara A., Kachel-Jakubowska M., Lorencowicz E. (2015). Combustion of plant biomass pellets on the grate of a low power boiler. Agriculture and Agricultural Science Procedia 7 (2), 131-138.

Kraszkiewicz A., Lorencowicz E., Kachel-Jakubowska M. (2015). Koszty produkcji peletów z biomasy roślinnej pochodzenia rolniczego. Conference Material "Innowacje w Zarzadzaniu i Inżynierii Produkcji" 1, 470-479. Available from: http://www.ptzp.org.pl/files/konferencje/kzz/artyk_pdf_2015/T1/t1_0470.pdf

Mitchell E.J.S. Lea-Langton A.R. Jones J.M. Williams A. Layden P. Johnson R. (2016). The impact of fuel properties on the emissions from the combustion of biomass and other solid fuels in a fixed bed domestic stove. Fuel Processing Technology. 142, 115-123.

Niedziółka I., Szpryngiel M., Kachel-Jakubowska M., Kraszkiewicz A., Zawiślak K., Sobczak P., Nadulski R. (2015). Assessment of the energetic and mechanical properties of pellets produced from agricultural biomass. Renewable Energy. 76, 312-317.

Olsson M. (2006). Residential biomass combustion - emissions of organic compounds to air from wood pellets and other new alternatives. Thesis for degree of doctor of philosophy, Chalmers University of Technology, Göteborg, Sweden.

Romeo L. M., Gareta R. (2006). Neural network for evaluating boiler behaviour. Applied Thermal Engineering Volume 26 (14-15), 1530-1536.

Valíček J., Palková Z., Harničárová M., Kušnerová M., Lukáč O. (2017). Thermal and Performance Analysis of a Gasification Boiler and Its Energy Efficiency Optimization. Energies 10 (7), 1066. 